\title{
NUMERICAL SIMULATION OF BOREHOLE MODEL WHICH UTILIZES LOW-POTENTIAL GEOTHERMAL HEAT
}

\author{
Richard LENHARD, Stanislav GAVLAS, Milan MALCHO` \\ Abstract: The article describes numerical simulation a device that was designed \\ as a scale model of two deep boreholes each of which withdraws the earth's heat \\ by heat transfer technology and heat carrier. Device using forced circulation of heat \\ carrier will respond in the construction of equipment currently used to transport \\ heat from deep borehole. Its construction solution enables to simulate features of \\ the ongoing processes in boreholes. Examining and analyzing the results of \\ numerical simulations of these processes to collect information on the most \\ appropriate heat carrier, power, heat transport and conductivity of rocks.
}

\section{INTRODUCTION}

Borehole model which utilizes low-potential geothermal heat it will serve to simulate the different heat flows corresponding heat flow in the borehole depth. The simulator will be set different sizes of heat flow are of different sizes along the height of the simulator. To the simulator will be connected devices for simulating the transport of heat from deep borehole into the heat transfer fluid for heating using forced circulation of heat carrier or without forced circulation of heat carrier. Equipment using forced circulation heat carrier will respond in the construction of equipment currently used to transport heat from deep borehole. Low-potential heat will be transported to the surface of the earth forced circulation medium to the heat exchanger, which will follow pumped heat pump.

For proper setup and operation of simulators wells is necessary to develop numerical simulations of these devices thereby avoiding potential problems that might arise after they have run into operation. Simulation results help us to correct setting using simulators, which will simulate the real conditions in wells.

\footnotetext{
•Ing.Ph.D., Richard Lenhard, Katedraenergetickejtechniky, Strojníckafakulta, Žilinskáuniverzita v Žiline, Univerzitná 1, Žilina, tel.(+421) 41513 2866, e-mail: richard.lenhard@fstroj.uniza.sk
}

This is an Open Access article distributed under the terms of the Creative Commons Attribution License 2.0, which permits unrestricted use, distribution, and reproduction in any medium, provided the original work is properly cited. 


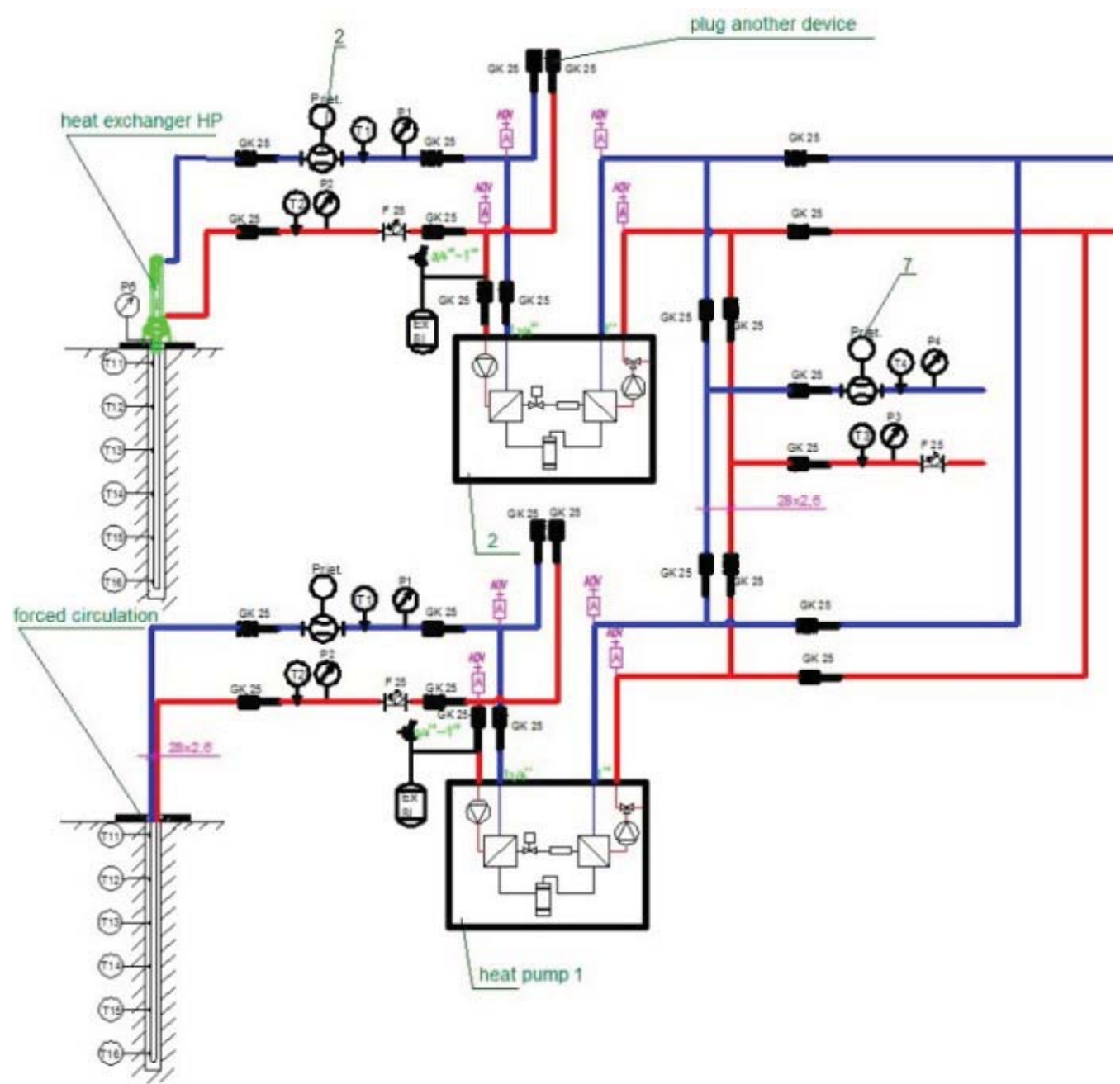

Figure 1: Equipment wiring diagram

2. NUMERICAL SIMULATION BOREHOLE MODEL FOR THE TRANSPORT OF GEOTHERMAL HEAT WITH FORCED CIRCULATION OF MEDIA

Numerical models (Figure 2) are developed on the basis of a real model of simulator designed to simulate a geothermal heat with forced circulation.

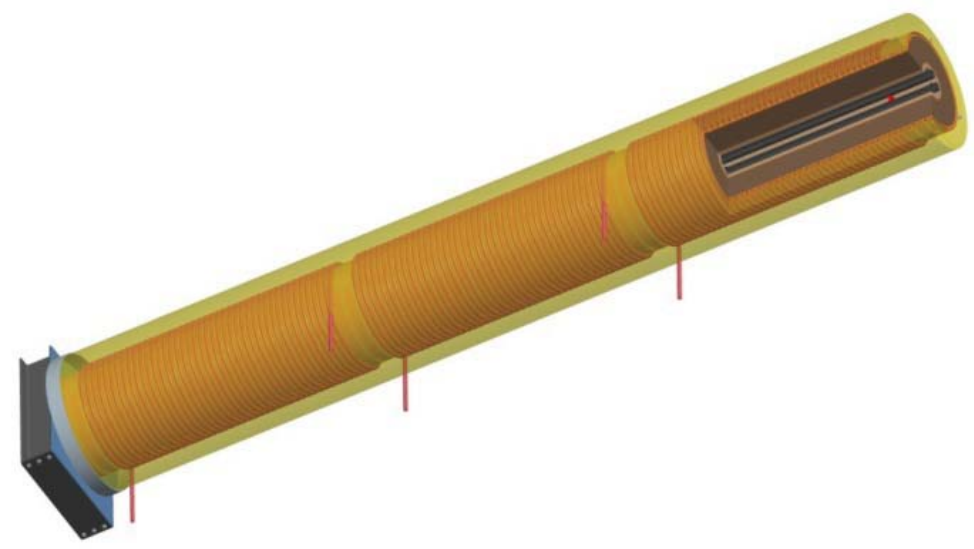

Figure 2: External and internal borehole simulator structure 
The Geometry model of simulator was created in the Gambit program according to already designed construction of simulator.

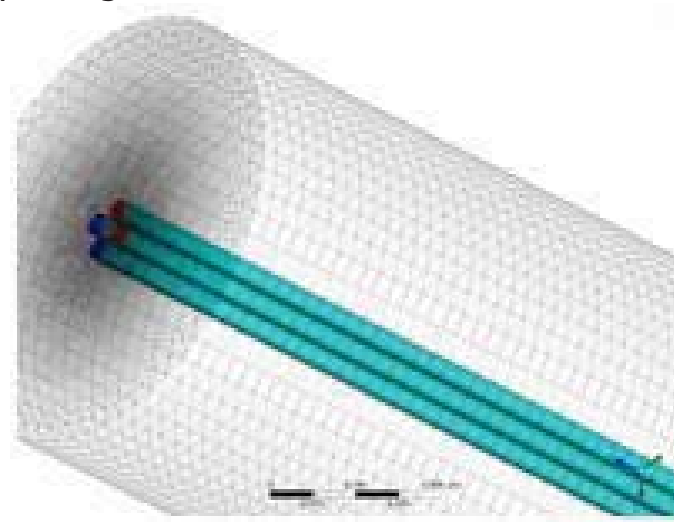

a. SIDE VIEW

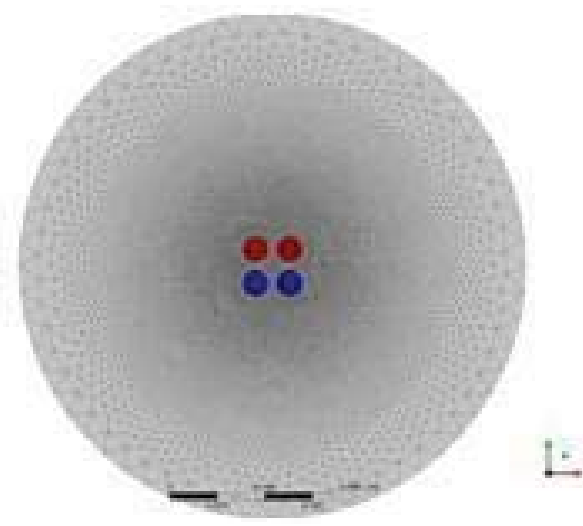

b. TOP VIEW

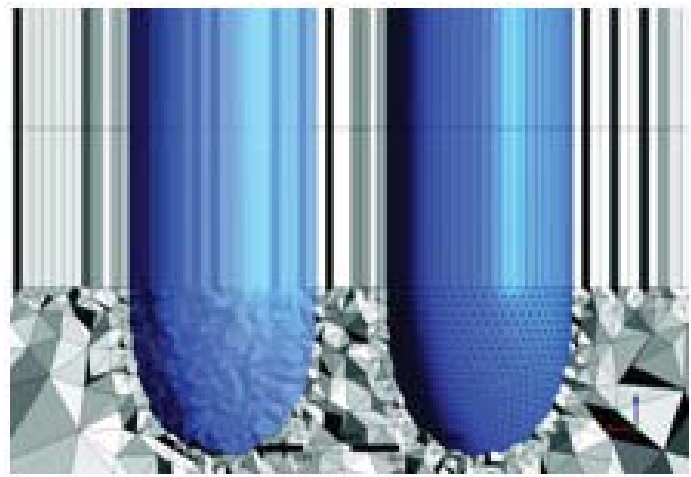

c. view of the mesh on U-tube

Figure 3: $\quad a, b, c-$ View of the mesh was created in a Gambit program

When creating a mesh for the CFD model in the Gambit program the first one of meshed was the bottom part, the elbows of the $U$ - tubes are located. First, were faces elbows meshed PAVE-type of mesh and elements TRI (Figure 3.c) was subsequently meshed volume as TGrid and elements Tet / Hybrid (Figure 3.c) The remaining part of the meshed model was swept mesh by default curve with the set of 150 elements. The type meshes Cooper with Hex / Wedge elements. This meshing process is already proven in previous CFD models, the heat devices.

After meshed has been given as a model for boundary zones (where geometry is fluid, solid and where is an input and an output). Thus formed was transferred to a model simulation Fluent program. Fluent program is commonly used CFD software, which defines boundary conditions (Figure 4) that are understood as a precondition for the correct calculation. The Turbulent model was as two - equations $k-\varepsilon$. This is the most widely tested and used a two- equation - transport- model (two transport equations for $k$ and $\varepsilon$ ). The $\mathrm{k}-\varepsilon$ model generally gives good results in simple flows as far as the means of the velocities and energies are concerned. But it cannot predict sufficiently the specific characteristics of complex flows (a recirculation of the regions, the secondary flows, etc.). 


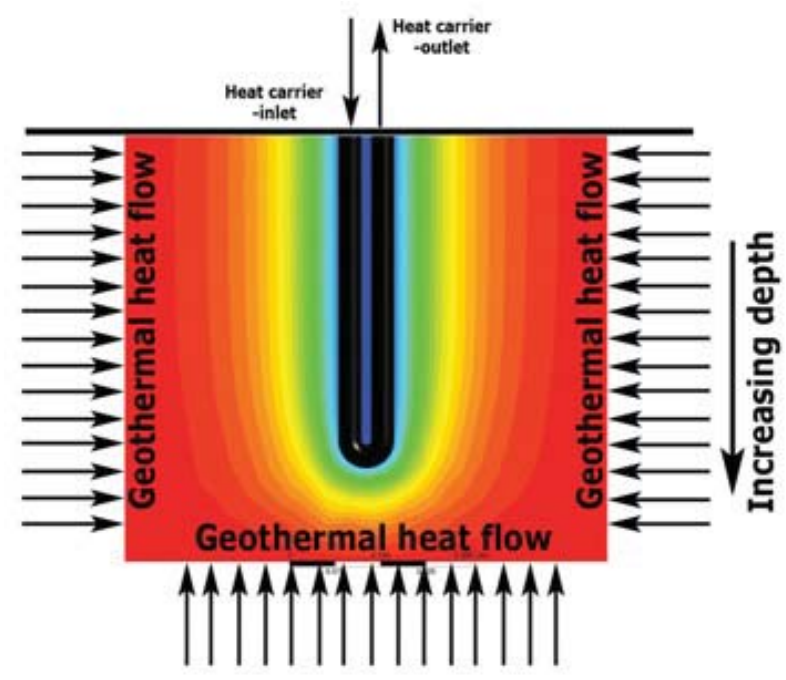

Figure 4: Boundary condition

Simulations were conducted for the following input conditions:

- temperature of soil,

- soil properties from fluent database,

- fluid temperature at the inlet,

- initial velocity of the heat carrier,

- media type and its physical properties (from fluent database).

The Temperatures of soil at various depths is shown in Figure 5.

\section{Dependence temperature on depth borehole}

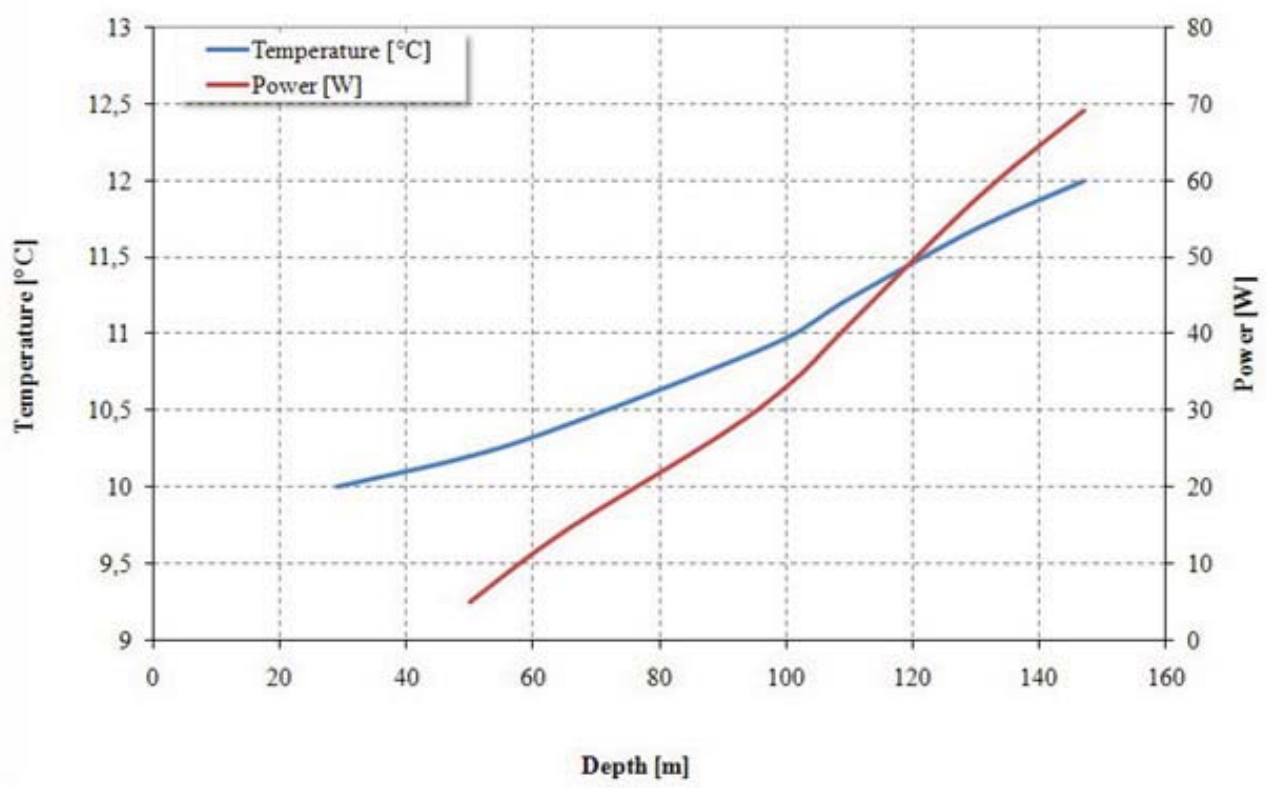

Figure 5: Dependence of power on temperature in a deep borehole

The Circulation medium in the $\mathrm{U}$-tube is water and the initial temperature is $10{ }^{\circ} \mathrm{C}$. The Achieved results are presented in Table 1.(Lenhard, R., Elsevier 2011) 


\section{THE RESULTS OF NUMERICAL SIMULATIONS}

The results of the simulation device for a low-potential transformation of the Earth's heat with a forced circulation are shown in Table 1. The dependence on power from a borehole depth of soil temperature is given in Figure 5 . This lists the performance results that are likely to achieve in the simulation of depth of the borehole with a device for transforming low-potential heat of the Earth with the forced circulation.

Table 1: Results of simulations

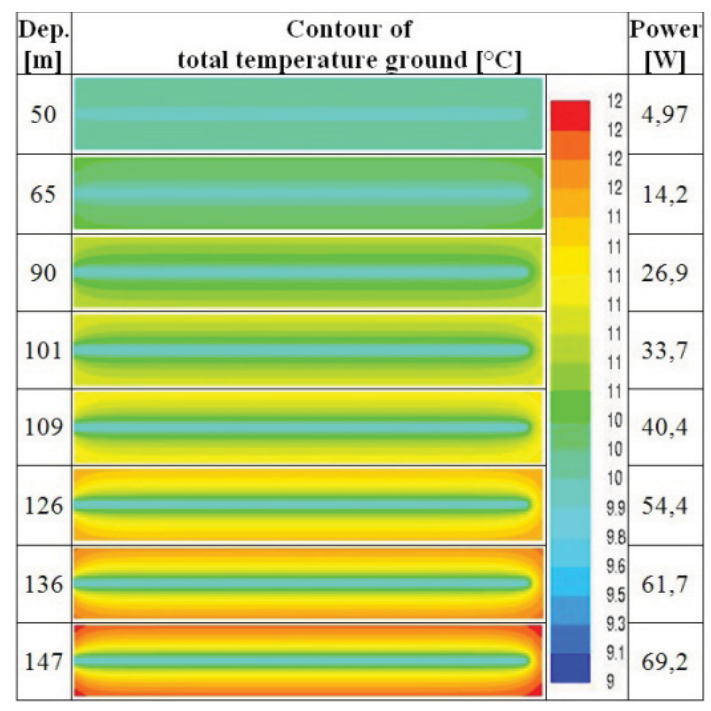

In the Tab.1 there are shown the vertical plane cuts through the axis of the simulator. Also the layout of temperature field in the simulator can be seen while simulating different depths of the estimated temperatures. In the Tab. 1, it is possible to monitor the selected temperature range, the heating of the soil and the transport of heat from it to the U-tubes. The results show that the simulation of heat flows with temperature near the soil temperature heat transfer fluid. So there is no significant heat transport from the soil into the $U$-tubes as it is in the simulations of larger depths where the temperature is higher and hence larger temperature gradients.(Lenhard, R., Jakubský, M., PCO 2010)

The Simulations were obtained by preliminary performances, which are gained in a real simulation device for a low-potential transformation of the Earth's heat with forced circulation.

\section{NUMERICAL SIMULATION BOREHOLE MODEL FOR THE TRANSPORT OF GEOTHERMAL HEAT WITHOUT FORCED CIRCULATION OF HEAT CARRIER WITH HEAT EXCHANGER}

Numerical model is developed on the basis of a real heat exchanger (Fig. 6) designed for borehole model to simulate a geothermal heat without forced circulation of heat carrier. 

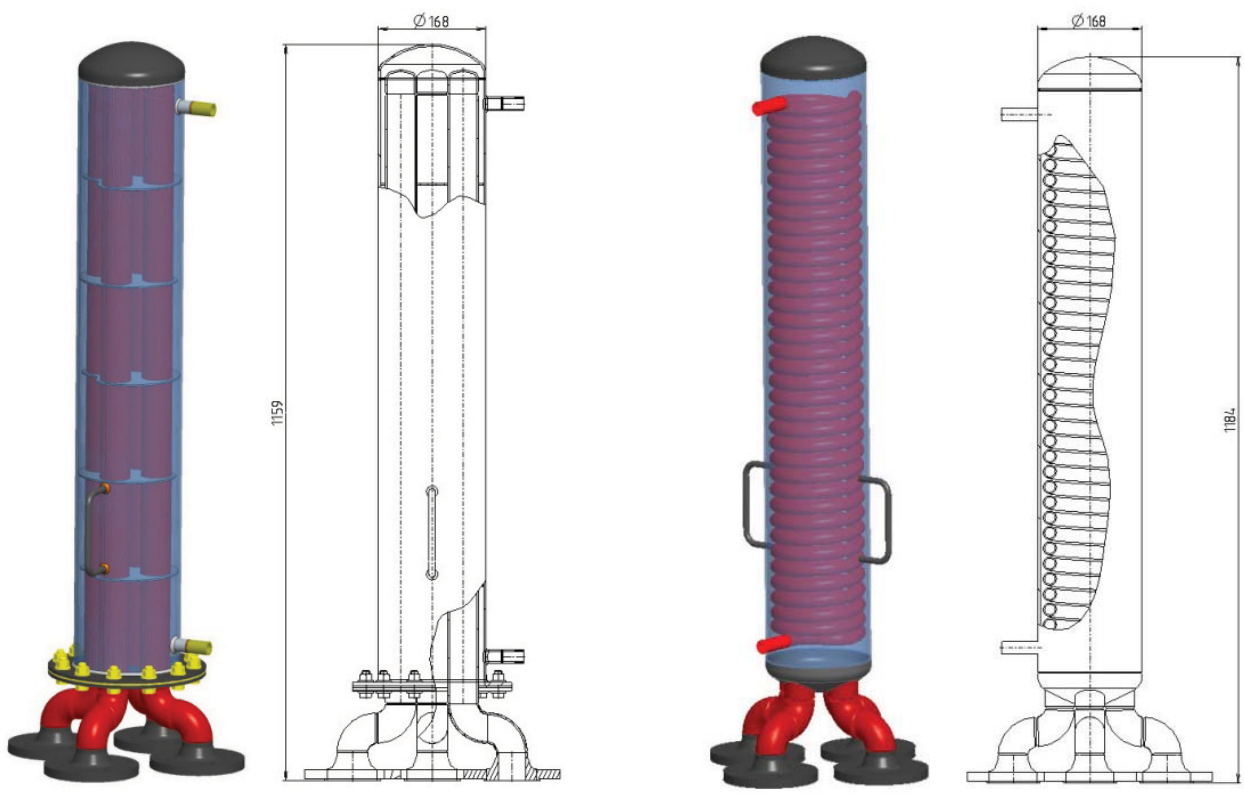

Figure 6: External and internal structure of heat exchangers for borehole model

It was developed two type counter flow heat exchangers, spiral (fig.7a) and dividers walls heat exchanger (fig.7b).

Simulations were conducted for the following input conditions:

- temperature of soil,

- soil properties from fluent database,

- fluid temperature at the inlet,

- initial velocity of the heat carrier,

- media type and its physical properties (from fluent database).

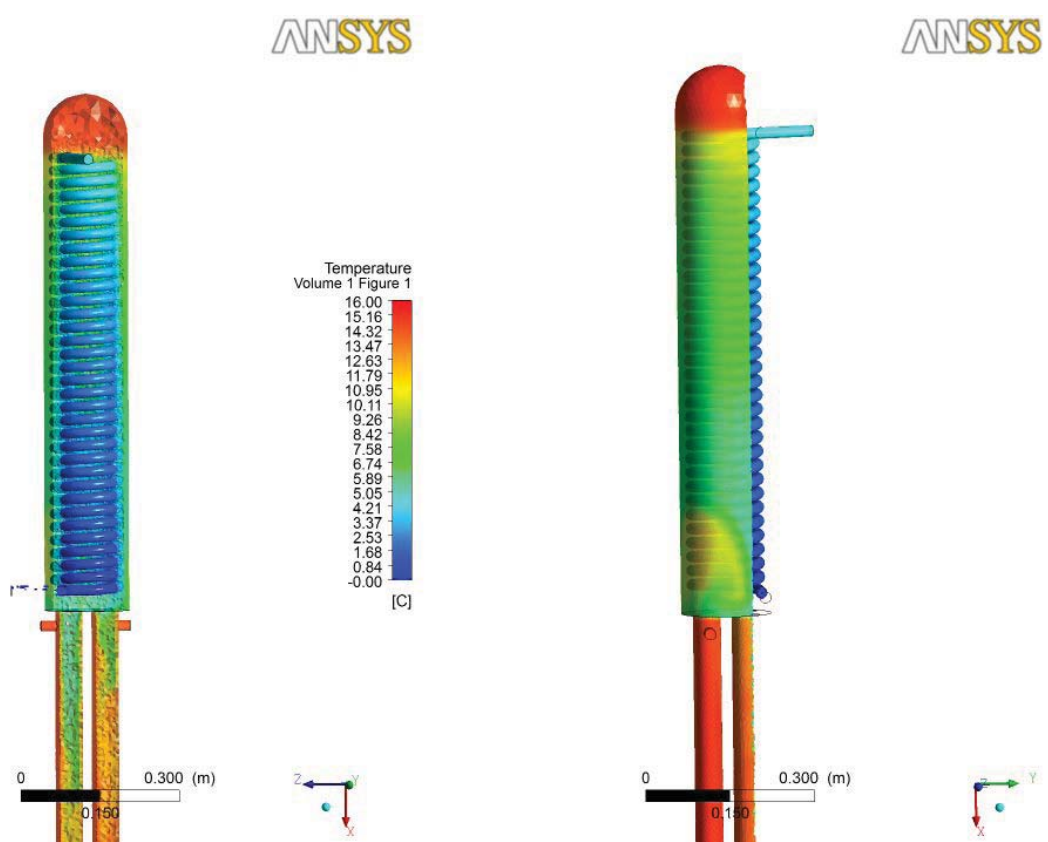

a. spiral heat exchanger 


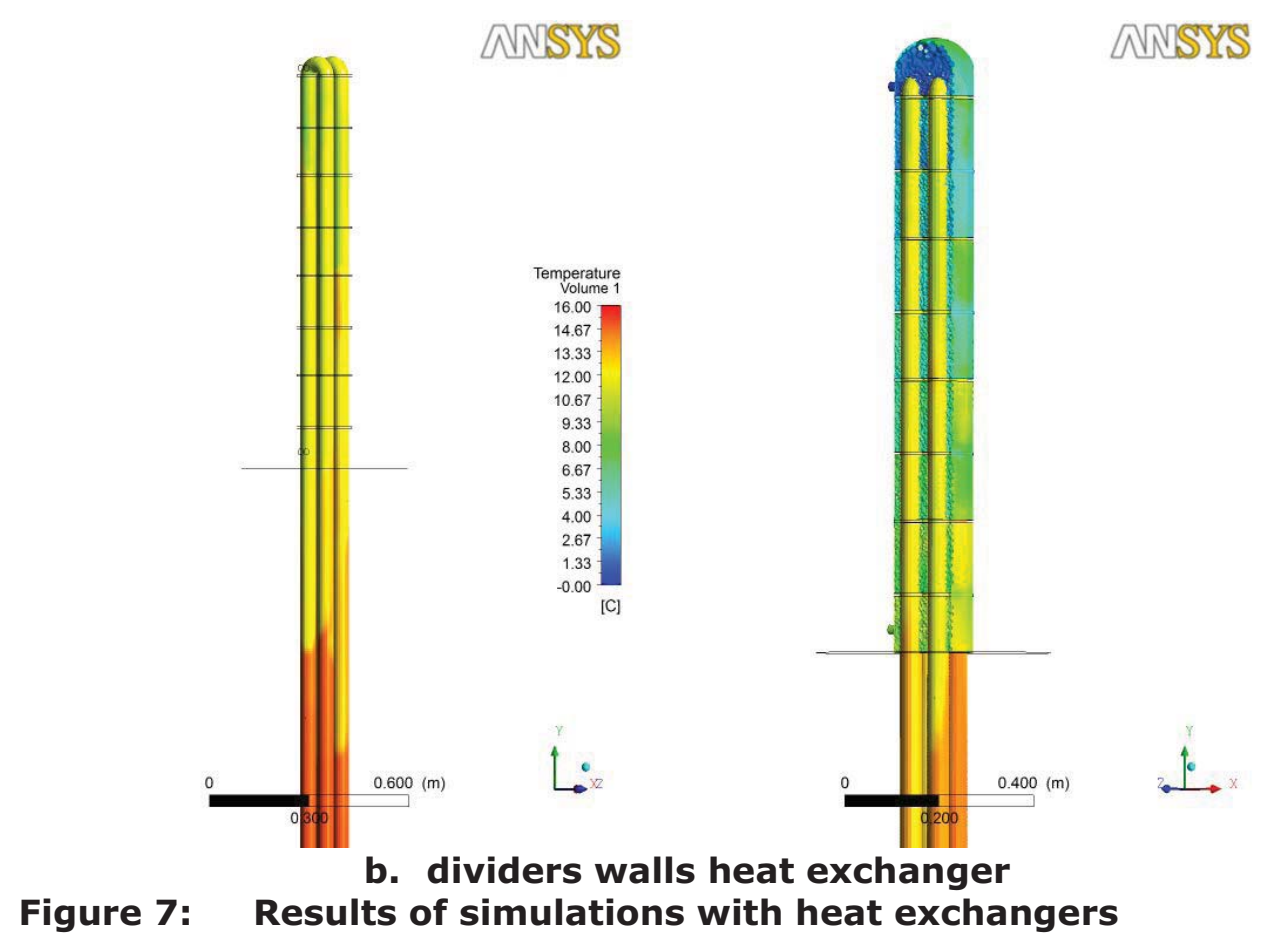

Simulations it was examined and analyzing the behaviour of these exchangers and which of them will be suitable for connection to a borehole model. Analyzing the results revealed that the spiral heat exchanger is preferable because it has a larger condensing surface and thus is more efficient condensation of the heat pipe that could unambiguously confirm this claim, the two heat exchangers will be tested on real devices. These results will be taken yet as to the information and measurements on real devices will be possible to evaluate the simulation results and the results obtained are sleep and these models can be used for further experimental simulations with different parameters.

\section{Conclusion}

This paper describes the construction design, the scheme and the involvement of the borehole model simulator, a creation of CFD model borehole model simulator and CFD simulation results of the borehole model simulator to simulate the transformation of low potential of geothermal energy to heat placed in a laboratory. The results of CFD simulations will be verified in a real simulator, if the results will comply with the CFD model, CFD model can be used for further simulations. The device to simulate a low transformation potential of geothermal energy to heat allows imitating the processes occurring in deep wells. By examining these processes in laboratory conditions it is about to obtain knowledge on the best heat transfer fluids, an exercise, a heat transfer, a conduction of the soil etc.

\section{ACKNOWLEDGEMENTS:}

The article was prepared under the Operational Program Research and Development, ITMS - 26220220057 "Zariadenie na využitie nízkopotenciálneho geotermálneho tepla bez núteného obehu tepelné honosiča v hlbokom vrte". 


\section{REFERENCES}

[1] Lenhard R., Malcho M.: Numerical Simulation Device for the Transport of Geothermal Heat with Forced Circulation of Media: Elsevier-An International Journal: Mathematical and Computer Modelling. - ISSN 0895-7177, doi: $10.1016 / \mathrm{j} . \mathrm{mcm} .2011 .06 .011$

[2] Lenhard, R., Jakubsky, M., Nemec, P.: Device for simulation of transfer geothermal heat with forced and without forced circulation of heat carrier, Fourth Global Conference on PCO 2010, Kuching - Sarawak - Malaysia 2010, ISBN 978-983-44483-32.

\section{FURTHER READING}

[1] Kapjor A., Jandačka J., Malcho M., Papučík.:Intenzifikácia transportu tepla z podlahového konvektora pridanej geometrii a spôsobu využitia, XXIX. Medzinárodná konferencia Setkání kateder mechaniky tekutin a termomechaniky; ročník 29, ISBN 978-80-248-2244-0. 2010.

[2] Čarnogurská M.,Základy matematického a fyzikálneho modelovania v mechanike tekutín a termodynamike, Košice, Vienala, ISBN 80 - 7099 - 344 - 8, 2000.

[3] Sýkora, D., Strážovec, I., Benčíková, J.: Vplyv geometrie teplozmenných plôch na prenos tepelnej energie systém upara-voda. Trendy $v$ technike prostredia, Zborník prednášok odbornej konferencie 4.- 5.5.1997, Novémesto nad Váhom,

[4] Nemec P., Čaja A.: Heat transfer intensification applying thermal tube, TU Košice, Acta Metallurgica Slovaca, 1/2009, ISSN 1335-1532, 2009. 